\title{
PENGEMBANGAN SUMBER DAYA MANUSIA KEOLAHRAGAAN (SURVEI MANAJEMEN SUMBER DAYA MANUSIA KEOLAHRAGAAN KABUPATEN \\ TAPANULI SELATAN TAHUN 2012)
}

\author{
Toktong Parulian Harahap \\ Universitas Islam Riau \\ toktongparulian@gmail.com
}

\begin{abstract}
ABSTRAK
Penelitian ini bertujuan untuk : (1) Mengetahui dan mendeskripsikan proses manajemen sumber daya manusia keolahragaan Kabupaten Tapanuli Selatan, (2) Mengetahui dan mendeskripsikan potensi sumber daya manusia keolahragaan Kabupaten Tapanuli Selatan. Metode yang dipakai dalam penelitian ini adalah deskriptif dengan mengambil tempat di kabupaten Tapanuli Selatan. Sampel yang digunakan adalah purposive (snowball), dan berkembang selama proses penelitian. Populasi dalam penelitian ini adalah seluruh pelaku sumber daya manusia keolahragaan yang ada di Kabupaten Tapanuli Selatan dengan jumlah sampel 177 orang. Teknik pengumpulan data yang digunakan adalah wawancara, observasi, kuesioner dan pengumpulan dokumen. Data-data yang terkumpul dianalisis menggunakan analisis interaktif yang meliputi reduksi data, penyajian data, dan penarikan simpulan serta verifikasi. Temuan penelitian di lapangan meliputi : (1) Proses manajemen sumber daya manusia keolahragaan yang dilakukan oleh Kabupaten Tapanuli Selatan telah memenuhi ketentuan-ketentuan berjalannya sebuah organisasi, yaitu berupa proses perencanaan, pengorganisasian, penggerakan dan pengawasan. (2) Potensi SDM keolahragaan Kabupaten Tapanuli Selatan secara umum belum berkembang dan belum maksimal. Hal itu terlihat dari hasil data yang diperoleh dari beberapa indikator, yaitu jumlah SDM keolahragaan, kualifikasi, profesi, keterlibatan dalam olahraga, prestasi dan kesejahteraan.
\end{abstract}

Kata kunci : Manajemen Sumber Daya Manusia Keolahragaan.

\section{PENDAHULUAN}

Dalam rangka pembangunan Indonesia yang sedang berkembang sekarang ini, pembangunan dan pengembangan dalam bidang olahraga diarahkan untuk mencapai cita-cita bangsa agar terbentuknya manusia Indonesia yang sehat jasmani maupun rohani serta terampil. Pembinaan dan pengembangan olahraga merupakan salah satu hakekat pembangunan olahraga nasional, kegiatan pembinaan dan pengembangan olahraga yang merupakan bagian upaya peningkatan sumber daya manusia yang utamanya ditujukan untuk pembentukan watak dan kepribadian termasuk sifat-sifat disiplin, sportivitas dan etos kerja yang tinggi. Berdasarkan kualitas kasehatan akan tercapai peningkatan prestasi olahraga yang dapat membangkitkan kebanggaan nasional dan membawa nama harum bangsa, (Ependi, S 2007:72). Dalam Undang-undang Nomor 3 Tahun 2005 Tentang sistem Keolahragaan Nasional juga menceritakan mengenai pembinaan dan pangembangan olahraga dapat dilakukan oleh setiap warga Negara dengan hak yang sama melalui: Melakukan kegiatan olahraga: memperoleh 
kegiatan dalam pelayanan olahraga; memilih dan mengikuti jenis atau cabang olahraga yang sesuai dengan bakat dan minatnya; memperoleh pengarahan, dukungan, bimbingan, pembinaan dan pengembangan dalam keolahragaan; dan menjadi pelaku olahraga, (Mutohir, T. C dan Maksum, A 2007:27 ).

Selain itu seiring dengan perkembangan olahraga, olahraga juga digunakan sebagai sarana untuk mengangkat harkat dan martabat. Hal tersebut dapat dicapai melalui prestasi yang membanggakan di bidang olahraga. (Kristianto, A 2012:16).

Untuk mencapai tujuan tersebut, Pemerintah kabupaten/kota wajib mengelola dam melakukan pembinaan dan pengembangan olahraga sesuai dengan kewenangan dan tanggung jawabnya. Pemerintah kabupaten/kota melaksanakan perencanaan pembinaan, pengembangan, penerapan standarisasi, dan penggalangan sumber daya keolahragaan yang berbasis keunggulan lokal.

Harsuki, (2012:8) menjelaskan manajemen olahraga dibagi dua bagian yaitu manajemen olahraga Pemerintah (berada dalam mata anggaran Depdiknas dan Depdagri) . dalam hal ini adalah Dinas Pendidikan Pemuda dan Olahraga Kabupaten Tapanuli Selatan yang akan mengelola manajemen sumber daya manusia dalam lingkup olahraga pendidikan dan olahraga rekreasi. Olahraga rekreasi dapat juga dilaksanakan oleh setiap orang, satuan pendidikan, lembaga, perkumpulan, atau organisasi olahraga. Sumber daya manusia dalam lingkup olahraga rekreasi sebagaimana dimaksud pada pasal 19 UUSKN bertujuan (1) memperoleh kesehatan, kebugaran jasmani, dan kegembiraan. (2) membangun hubungan sosial. (3) melestariakn dan meningkatkan kekayaan budaya daerah dan nasional. Sedangkan sumber daya manusia dalam lingkup olahraga pendidikan sebagaimana dimaksud pada pasal 18 UUSKN dibimbing oleh guru/dosen olahraga dan dapat dibantu oleh tenaga keolahragaan yang disiapkan oleh setiap satuan pendidikan. Olahraga pendidikan dilaksanakan baik pada jalur pendidikan formal maupun non formal melalui kegiatan intrakurikuler dan/atau ekstrakurikuler. Sedangkan manajemen sumber daya manusia keolahragaan dalam lingkup olahraga prestasi Pemerintah kabupaten/kota dalam pengembangan olahraga akan dibantu oleh Komite Olahraga Nasional (KON), sebagaimana dimaksud pada UUSKN pasal 36 tentang pengelolaan keolahragaan. Komite Olahraga Nasional mempunyai tugas membantu Pemerintah dalam membuat kebijakan nasional dalam bidang pengelolaan, pembinaan dan pengembangan olahraga prestasi berdasarkan kewenangannya (Harsono, 2012:8)

Sehubungan dengan itu, pemerintah daerah Kabupaten tapanuli selatan, komite olahraga nasional (KON) Kabupaten Tapanuli Selatan, satuan pendidikan, lembaga, perkumpulan dan organisasi olahraga sebagai pengelola dalam pengembangan olahraga di daerah perlu menyikapi fenomena ini dan membuat langkah-langkah setrategis untuk pengembangan olahraga di Kabupaten Tapanuli Selatan. Salah satu langkah yang mendasar perlu dilakukan adalah perlunya data empiric tentang sumber daya manusia olahraga pendidikan, olahraga rekreasi dan olahraga prestasi. Dalam konteks tersebut penelitian ini penting dilakukan untuk mengetahui pelaksanaan manajemen sumber daya manusia Keolahragaan di KONI Kabupaten Tapanuli Selatan.

Bertitik tolak dari latar belakang di atas, maka dapat dirumuskan judul dalam penelitian ini adalah "Pengembangan Sumber Daya Manusia Keolahragaan, dengan sub judul Survei Manajemen Sumber Daya Manusia Keolahragaan Kabupaten Tapanuli Selatan Tahun 2012)". 


\section{METODE PENELITIAN}

Penelitian ini bersifat kualitatif dengan metode deskriptif. Data dikumpulkan melalui wawancara langsung, angket dan obeservasi. Sumber data dalam penelitian ini adalah para pelaku keolahragaan yang ada di kabupaten Tapanuli Selatan yaitu Pembina Olahraga, Atlet, Pelatih Olahraga, Guru Olahraga, Instruktur Olahraga, Psikolog Olahraga, Fisioterapi Olahraga dan Tenaga Medis Keolahragaan. Adapun penarikan sampel yang digunakan adalah purposive sampling. Analisis data dilakukan secara kualitatif dengan metode analis interaktif yang meliputi empat tahap yaitu (1) tahap pengumpulan data, (2) tahap reduksi data (3) tahap penyajian data (4) tahap penarikan kesimpulan/ verifikasi.

\section{HASIL PENELITIAN DAN PEMBAHASAN}

\section{Manajemen Sumber Daya manusia Keolahragaan}

Dari hasil penelitian dan analisis data yang terkumpul, dapat diketahui bahwa Pemerintah Kabupaten Tapanuli Selatan Telah telah melaksanakan proses perencanaan manajemen keolahragaan Kabupaten Tapanuli Selatan ditentukan pada Musorda yang diselenggarakan setiap 4 (empat) tahun untuk menetapkan program kerja dalam hal ini Komite Olahraga Nasional Kabupaten Tapanuli Selatan dalam waktu 4 (empat) tahun mendatang dan program kerja tahunan (jangka pendek) disusun pada Raparda yang dilaksanakan setiap 1 (satu) tahun sekali dengan mengacu pada rencana kerja yang ditetapkan pada Musorda. Program kerja pemerintah Kabupaten Tapanuli Selatan terdiri dari rencana kerja (kegiatan) Kabupaten Tapanuli selatan sesuai denga tugas dan wewenang tiap bidang pada kepengurusan dalam mengembangak SDM keolahragaan Kabupaten Tapanuli selatan.

Pengorganisasian sudah dilakukan oleh pemerintah Kabupaten Tapanuli Selatan dalam hal ini Komite Olahraga Nasional terbukti dengan adanya struktur organisasi dalam suatu kepengurusan berdasarkan kebutuhan organisasi dalam melaksanakan aktivitas dan disusun sesuai kedudukan dalam rangka mencapai tujuan organisasi. Dalam kepengurusan terdapat beberapa bidang dan komisi yang tugas, wewenang dan garis koordinasi telah ditetapkan pada AD/ART. Prinsip-prinsip dalam organisasi telah dilaksanakan Kabupaten Tapanuli Selatan dalam melaksanakan aktivitas.

Dalam melaksanakan proses penggerakan pemerintah Kabupaten Tapanuli Selatan dilaksanakan dengan menggerakkan anggota-anggotanya dalam pelaksanaan aktivitas organisasi sesuai dengan kedudukan, tugas dan fungsi dari masing-masing. Penggerakan yang dilakukan pemerintah Kabupaten Tapanuli Selatan dilakukan sejalan dengan pelaksanaan kegiatan yang dilaksanakan oleh serta dimaksudkan agar anggota menjalankan aktivitas dengan disiplin dan tanggung jawab sesuai dengan tugas dan kewajiban dalam kepengurusan agar tujuan dalam organisasi dapat dijalankan sesuai harapan. Dalam proses penggerakan tidak lepas dari adanya sarana penunjang manajemen yang salah satunya adalah pendanaan organisasi, Untuk melaksanakannya penggerakan manajemen SDM keolahragaan Kabupaten Tapanuli Selatan mendapatkan dana untuk pelaksanaan organisasi berasal dari APBD Kabupaten Tapanuli selatan.

Seperti yang dilakukan pada proses penggerakan tersebut, proses pengawasan SDM keolahragaan Kabupaten Tapanuli Selatan dilaksanakan sejalan dengan pelaksanaan kegiatan-kegiatan keolahragaan Kabupaten Tapanuli Selatan. 
Pelaporannya dilaksanakan pada pelaksanaan Musorda sebagai laporan pertanggungjawaban kerja selama 4 (empat) tahun dan Raparda sebagai laporan pertanggungjawaban kerja selama 1 tahun. Laporan berisi tentang rangkuman dari hasil kegiatan-kegiatan keolahragaan yang dilaksanakan di Kabupaten Tapanuli Selatan pada periode waktu tertentu. Selain pelaporan tersebut, juga diawasi oleh masyarakat serta BPK yang bertugas memeriksa laporan keuangan.

Dari uraian tersebut, pemerintah Kabupaten Tapanuli Selatan telah melaksanakan rangkaian proses manajemen mulai dari proses perencanaan, pengorganisasi, penggerakan dan pengawasan walaupun masih terdapat beberapa kekurangan merupakan sesatu hal yang wajar.

\section{Pengembangan Sumber Daya Manusia Keolahragaan Olahragawan}

Kabupaten Tapanuli Selatan dalam pemberdayaan atlet belum maksimal. Pemetaan pengembangan atlet tidak merata, pemerintah daerah masih pilih bulu dalam melakukan pembinaan dan pengembangan di daerah, banyak atlet-atlet yang bukan cabang dari cabang olahraga popular tidak diperhatikan, sehingga potensi atlet tidak berkembang. Akan tetapi ada juga atlet yang berkembang sehingga dapat berprestasi ditingkat provinsi. Akan tetapi itu masih sangat sedikit sekali disbanding jumlah atlet di cabang olahraga yang ada.

Penyediaan dan penerapan sistem penghargaan bagi atlet perlu dioptimalkan pemerintah daerah. Secara prinsip pembinaan atlet perlu disertakan dengan perencanaan karier terutama setelah mereka tidak lagi aktif lahi sebagai atlet. Pemberian penghaargaan mengacu pada Undang-Undang No. 3 Tahun 2005 Tentang sistem Keolahragaan Nasional.

\section{Pembina Olahraga \\ a. Pembina Cabang Olahraga}

Pembina cabang olahraga pada tingkat pusat dan tingkat daerah yang telah dipilih/ditunjuk menjadi pengurus. Pembina cabang olahraga melakukan pembinaan dan pengembangan olahraga sesuai dengan tugas dan fungsinya dalam organisasi. Pembina cabang olahraga berhak memperoleh peningkatan pengetahuan keterampilan, penghargaan, dan bantuan hukum.

Pembina cabang olahraga sudah ada setiap cabang olahraga di Kabupaten Tapanuli Selatan. Rata-rata adalah mantan atlet juga, tetapi mereka tidak pernah mendapat penetaran/pengkaderan tentang Pembina cabang olahraga. Harusnya mereka berhak memperoleh peningkatan pengetahuan dari pemerintah daerah. Pembina cabang olahraga ini sudah melaksanakan pembinaan dan pengembangan olahraga di setiap pengcab masing-masing. Namun masih ada kekurangan Pembina cabang olagraga ini, seperti minimnya melakukan kejuaraan/kompetisi guna mengembangkan potensi atletnya.

\section{b. Pembina Perkumpulan Olahraga}

Pembina perkumpulan olahraga berhak memperoleh peningkatan pengetahuan keterampilan, penghargaan, dan bantuan hukum. Harusnya Pembina perkumpulan olahraga juga mendapat perhatian dari pemerintah derah. Biar bagaimana pun pebina perkumpulan olahraga juga tetap berpengaruh terhadap masa depan SDM keolahragaan. 
Tidak melakukaan pembiaraan karena beranggapan tidak terlibat langsung terhadap pengembangan SDM keolahragaan. Pembina cabang olahraga juga berhak mendapatkan pengembangan dan pengetahuan dari pemerintah.

\section{Tenaga Keolahragaaan \\ a. Pelatih}

Pada dasarnya jumlah pelatih yang ada di Kabupaten Tapanuli Selatan sudah cukup banyak. Termasuk yang sudah memiliki licenci untuk melatih, namun masih kurang berkembang. Ada beberapa hal yang menyebabkan belum berkembangnya pelatih di Kabupaten Tapanuli Selatan, antara lain; masih minimnya club olahraga yang menjadi tempat mereka untuk mengembangkan kepelatihannya, minimnya kejuaraan/kompetisi yang diadakan dan para pelatih cabang olahraga olahraga yang bukan prioritas daerah seperti dianak tirikan pemerintah Kabupaten Tapannuli Selatan, hanya para pelatih cabang olahraga unggulan yang mendapat perhatian dari pemeriatah.

Masa depan pelatih juga masih tergantung pada hasil kerja mereka, seperti terlibat dalaam kejuaraan, mereka tidak mendapat pekerjaan rutin dari Pengcab masingmasing.

\section{b. Guru Olahraga}

Dari segi kulifikasi guru olahraga di Kabupaten Tapanuli Selatan cukup bagus, rata-rata mereka adalah lulusan sarjanaolahraga dan SGO. Mereka juga memahami tugas dan fungsi guru. Namun karena menurut mereka gaji/pendapatan sebagai guru olahraga masih kurang untuk kebutuhan keluarga, mereka banyak yang berprisip cukup mengajar saja, tidak memperdulikan kegiatan-kegiatan ektraakurikuler demi mebuka usaha dan bertani untuk medapat gaji sampingan.

Hanya sedikit dari guru-guru olahraga yang terlibat langsung dalam kegiatankegiatan olahraga yang diselengarakan oleh Dinas Pendidikan.

\section{c. Wasit}

Di Kabupaten Tapanuli Selatan sendiri jumlah wasit cukup banyak. Namun rata-rata dari mereka banyak yang tidak bersertifikat/licenci, hanya para wasit cabang olahraga populer yang memiliki licenci, seperi sepakbola dan bola volley. Hal tersebut dikarenakan kurang perhatiannya pemerintah Kabupaten Tapanuli Selatan terhadap wasit olahraga non unggulan di daerah. Pemerintah Daerah tidak pernah membuat penataran untuk para wasit untuk memperoleh licenci. Kondisi seperti membuat potensi mereka tidak berkembang, dan hasil/upah profesi perwasitannya pun tidak maksimal. Harusnya pemerintah daerah lebih perhatian lagi terhadap profesi perwasitan, biar bagaimapun pertandingan olahraga tidak akan berjalan sempurna tanpa kualitas wasit yang baik.

\section{d. Instruktur Olahraga}

Profesi instruktur tidak berjalan di Kabupaten Tapanuli Selatan. Selain karena minimnya minat masyarakat terhadap olahraga rekreasi seperti senam, finess, outboand, yoga, dan olahraga tradisional lainnya, wadah untuk melakukan kegiatan olahraga rekreasi pun hanya sedikit. Hal tersebut yang menyebabkan profesi instruktur tidak berkembang. Adapun instruktur di Kabupaten Tapanuli Selatan, belum memiliki 
sertifikat. Mereka hanya mengandalkan bakat dan pengalamannya saja, tidak penah ikut penataran. Pemerintah daerah tidak pernah membuat penataran guna mendapatkan sertifikat. Mereka hanya medapatkan upah dengan membuat kelompok untuk melakukan kegiatan, dan mendapat iuran bulanan daari peserta kegiatan. Harusnya instruktur sudah pernah mendapatkan penataran guna mengaplikasikan ilmu yang didapat ke masyarakat sebaik-baiknya. Dalam hal ini harusnya pemerintah daerah turut serta menfasilitasi para instruktur olahraga, termasuk membuat penataran-penataran instruktur olahraga.

\section{e. Tenaga Medis}

Di Kabupaten Tapanuli Selatan tenaga medis profesional tidak terlalu dibutuhkan, Tenaga medis hanya dibutuhkan pada saat ada kejuaraan saja. Club-club olahraga masih lebih percaya kepada tenaga kesehatan tradisional seperti tukang pijat dan masseur kampung. Pada hal ada tenaga medis yang sudah terjamin keprofesiannya. Dilain memang profesi tenaga medis yang masih sangat jarang, jasa tenaga medis juga tidak dimanfaatkan semaksimal mungkin. Padahal tenaga medis juga memiliki peran yang sangat penting untuk perkembanagan olahragawan, termasuk memanej kesehatan olahragawan. Hal ini harus lebih diperhatikan para pengrus pengcab olahraga maupun club-club olahraga demi kesehatan olahragawan.

\section{f. Ahli Gizi}

Peran ahli gizi adalah sebagai partner pelatih dalam mengoptimalkan performa atlet. Seorang ahli gizi professional adalah orang yang memiliki basis ilmu dan nutrisi, sesuai dengan prinsip dasar gizi.Ahli gizi dibutuhkan keberadaannya demi perkembangan prestasi atlet. Profesi ahli gizi memang sangat sedikit di Kabupaten Tapanuli Selatan. Harusnya ini harus lebih dimanfaatkan secara maksimal. Namun yang terjadi di lapangan ahli gizi sama sekali tidak pernah dilibatkan dalam kegiatan keolahragaan. Hal ini sangat disayangkan karena seorang ahli gizi juga pada dasarnya adalah pembantu sebuah tim olahraga untuk meningkatkan performa atlet dalam bidang stamina dan kesehatannya.

\section{KESIMPULAN}

Berdasarkan temuan penelitian dan pembahasan hasil penelitian maka dapat disimpulkan sebagai berikut:

1.Manajemen SDM keolahragaan

Proses manajemen SDM keolahragaan yang dilakukan oleh Kabupaten Tapanuli Selatan telah memenuhi ketentuan-ketentuan berjalannya sebuah organisasi, yaitu berupa proses perencanaan, pengorganisasian, penggerakkan dan pengawasa

2. Sumber Daya Manusia Keolahragaan

Secara umum Sumber Daya Manusia keolahragaan di Kabupaten Tapanuli Selatan belum berkembang, perhatian pemerintah daerah terhadap pengembangan SDM keolahragaan tidak maksimal.

\section{DAFTAR RUJUKAN}

Kristiyanto, A. 2012. Pembangunan Olahraga Untuk Kesejahteraan Rakyat dan Kejayaan Bangsa. Surakarta : Yuma Pustaka 
Harsono. (2000). Rencana Induk Pengembangan Olahraga Prestasi di Indonesia

Harsuki. 2012. Pengantar Manajemen Olahraga. Jakarta: Rajawali Pers

KONI Kabupaten Tapanuli Selatan. 2004. Laporan Pelaksanaan Musyawarah Daerah (MUSORDA)KONI Kabupaten Tapanuli Selatan.Tapanuli Selatan: KONI Kabupaten Tapanuli Selatan

Efendi, S. 2007. Pengembangan Olahraga Prestasi.

Mutohir, T. C dan Maksum, Ali. 2007. Sport Development Index : Metodologi, Konsep dan Aplikasi. Jakarta: PT. Index

Undang-undang Republik Indonesia. Nomor 3 Tahun 2005 Tentang Sistem Keolahragaan Nasional. Jakarta;Kementerian Negara Pemuda dan Olahraga Republik Indonesia 